\title{
Penguatan Daya Saing Usaha Mikro Kecil Menengah Melalui E-Commerce
}

\author{
Irsad Andriyanto \\ Institut Agama Islam Negeri Kudus \\ (irsad.smg@gmail.com)
}

\begin{abstract}
MSMEs have faced many challenges, especially in marketing its products, consequently the use of information technology is a necessity in the midst of rapid business changes. This study aimed to analyze the use of e-commerce in strengthening MSMEs competitiveness in terms of operations and marketing. The research took place in Kudus, a city that is pro-investment, where there are many MSMEs with various business fields. The respondents were the owners of the embroidery business in Padurenan village that was the center of the embroidery and convection industry in Kudus. They were asked about the use of e-commerce in supporting their business in terms of operation and marketing activities. Data then analyzed through qualitative technique analysis in order to conclude the research problem. As the results of the study, it's concluded that the use of e-commerce impacted on broader marketing area, cost reduction, more relation, ease of transaction, and additional income. Besides there were some concequencies such as higher competition, plagiarism, and prone to fraud recognized as threats of the e-commerce implementation.
\end{abstract}

Keywords: empowerment, competitiveness, e-commerce, threats, marketing.

\section{A. Pendahuluan}

Teknologi informasi memiliki peran yang sangat penting bagi kehidupan manusia dan mengalami perkembangan yang sangat luar biasa pada saat ini. Teknologi informasi atau sering dikenal dengan istilah Information Technology (IT) adalah istilah umum untuk teknologi apapun yang membantu manusia dalam membuat, mengubah, menyimpan, mengomunikasikan dan/atau menyebarluaskan informasi. IT melakukan komputasi dan komunikasi berkecepatan tinggi untuk data, suara dan video (Williams, Dwivedi, Lal, \& Schwarz, 2009). Hampir seluruh kegiatan sehari-hari kita didukung oleh IT tersebut. Banyak masyarakat yang mengakses internet dalam kehidupan sehari-hari untuk mencari toko, informasi seputar hiburan, tempat makan, berita, atau informasi untuk berbelanja, tidak terkecuali para pengusaha dalam menjalankan bisnisnya. Terlebih pada perusahaan besar, hampir semuanya menggunakan teknologi informasi sebagai pendukung aktivitas yang vital dalam meningkatkan layanan bisnis yang dikelola. IT berupa internet semakin mudah diakses untuk dimanfaatkan para pengusaha melakukan praktek pemasaran dan bisnis dengan leluasa dan tanpa batas.

Dengan perkembangan teknologi tersebut, persaingan bisnis akan menjadi lebih seru dan tidak hanya di dunia nyata tetapi juga di dunia maya. Dunia bisnis makin semarak sehingga menciptakan iklim persaingan yang sangat kompetitif, cepat, dan sulit untuk diprediksi. Semua produsen baik produsen barang maupun jasa dituntut untuk terus menerus melakukan perbaikan, penyempurnaan, dan bahkan inovasi-inovasi baru untuk meningkatkan daya saingnya. Banyak perusahaan besar yang menjalankan bisnisnya melalui internet atau biasa disebut e-commerce. E-commerce atau yang disebut juga perdagangan elektronik adalah 
"penggunaan jaringan komunikasi dan komputer untuk melaksanakan proses bisnis" (Morrison, Breen, \& Ali, 2003). E-commerce sendiri merupakan bagian dari e-business yang selain menggunakan teknologi jaringan, juga menggunakan teknologi basis data (database), surat elektronik (e-mail), dan bentuk teknologi non-komputer lain seperti halnya sistem pengiriman barang, dan alat pembayaran. Dikutip dari laman detik.com berdasarkan riset terbaru dari google di tahun 2017 penjualan e-commerce mencapai USD 10,9 miliar. Jumlah ini meningkat $41 \%$ dari angka USD 5,5 miliar yang dicapai pada tahun 2015. Laporan google juga menyebutkan ketertarikan konsumen terhadap e-commerce tumbuh pesat di Asia Tenggara lebih dari dua kali lipat dalam 2 tahun terakhir. Fakta menunjukkan bahwa tidak hanya perusahaan besar yang memanfaatkan IT, perusahaan kecil dan menengah pun memanfaatkan IT dalam memasarkan produknya yang diharapkan akan menghemat biaya, waktu, dan tenaga sehingga dapat menciptakan harga jual yang mampu bersaing di pasaran. Dengan demikian konsumen akan memperoleh harga yang rendah dibandingkan dengan pembelian secara tradisional yang dilakukan secara manual.

Usaha Mikro Kecil Menengah (UMKM) telah menjadi bagian penting dari sistem perekonomian nasional yang mampu mempercepat pertumbuhan ekonomi melalui misi penyediaan lapangan usaha dan lapangan kerja, peningkatan pendapatan masyarakat, berperan dalam meningkatkan perolehan devisa serta memperkokoh struktur ekonomi nasional (Hafni \& Rozali, 2017). Keberadaan UMKM di Kabupaten Kudus sangat mewarnai dinamika kehidupan sektor ekonomi. Desa Padurenan yang terletak di Kecamatan Gebog Kabupaten Kudus merupakan sentral industri konfeksi dan bordir yang terkenal di Kabupaten Kudus. Setidaknya terdapat sekitar 160 UMKM pengerajin bordir dan konfeksi yang berkembang di Desa Padurenan dan mampu menyerap sekitar 1500 tenaga kerja. Sebagian besar hasil produk dipasarkan di wilayah Jawa Tengah, Jawa Timur, Bali, dan daerah lain.

Meskipun IT semakin maju, namun masih banyak UMKM yang belum memanfaatkan kecanggihan IT melalui aplikasi e-commerce dan masih belum optimal dalam memanfaatkan TI. Dengan banyaknya faktor yang menyebabkan kurangnya pemanfaatan IT berdampak pada lemahnya daya saing dan ketertinggalan dengan perusahaan-perusahaan besar yang sudah memanfaatkan IT dengan menggunakan bisnis online (e-commerce) sebagai alat pemasaran yang efektif dan efisien (Tan, Tyler, \& Manica, 2007). Seiring dengan persaingan bisnis yang semakin tinggi dan minimnya pemanfaatan e-commerce dalam pengembangan bisnis UMKM, maka pengkajian mendalam mengenai peningkatan daya saing UMKM menjadi suatu hal yang penting. Oleh karena itu, penelitian ini ditujukan untuk mengetahui persepsi para pengusaha UMKM terhadap pemanfaatan teknologi informasi e-commerce, menganalisis faktor pendorong dan penghambat pemanfaatan teknologi informasi $e$ commerce, dan untuk mengetahui dampak pemanfaatan e-commerce terhadap peningkatan daya saing UMKM di Desa Padurenan Kudus. 


\section{B. Kajian Pustaka}

\section{Usaha Mikro Kecil Menengah}

Sebagai ilustrasi, permasalahan yang dialami UMKM dalam arti luas dapat dijelaskan oleh 7 (tujuh) faktor/karakteristik berikut (Niode, 2009):

a) Kesulitan pemasaran

Kesulitan masalah pemasaran akan bertambah serius pada negara-negara yang mengalami krisis keuangan (contohnya pada saat krisis moneter pada tahun 1998 yang melanda negara-negara Asia seperti Indonesia, Filipina, Thailand, dan Korea Selatan) karena sulitnya akses untuk mendapatkan pinjaman/kredit dari kreditor (bank). Akibatnya, banyak UMKM yang tidak memiliki sumber daya produksi dan tidak mampu memperbaiki mutu produknya, serta sulit untuk mempertahankan jaringan pemasarannya baik di pasar domestik maupun pasar internasional.

b) Keterbatasan Finansial

Banyaknya kredit perbankan saat ini tidak menjamin terpenuhinya kebutuhan finansial UMKM sehingga sumber-sumber pendanaan dari sektor informal masih tetap dominan di dalam pembiayaan UMKM. Hal ini disebabkan oleh sejumlah alas an seperti lokasi bank terlalu jauh bagi pengusaha yang tinggal di daerah yang relatif terisolasi, persyaratan kredit terlalu berat, kurangnya infomasi mengenai skim-skim perkreditan yang ada beserta prosedurnya. Hal lainnya adalah sistem pembukuan yang relatif sederhana dan cenderung tidak mengikuti kaidah administrasi pembukuan standar, atau kadang kala pembukuan oleh UMKM tidak up to date sehingga menyulitkan dalam penilaian kinerja usahanya dan sulit mendapatkan dana dari pasar modal, serta margin usaha yang cenderung kecil sebagai dampak persaingan dengan perusahaan bermodal besar.

c) Keterbatasan SDM

Keterbatasan SDM merupakan salah satu kendala serius bagi banyak UMKM, terutama dalam aspek-aspek kewirausahaan, manajemen, teknik produksi, pengembangan produk, perancangan teknik, pengendalian dan pengawasan mutu (quality control). Semua keahlian ini mutlak dibutuhkan untuk mempertahankan dan/atau memperbaiki mutu produk, meningkatkan efisiensi dan produktivitas, dan memperluas pangsa pasar dan menembus pasar baru.

d) Masalah bahan baku

Keterbatasan bahan baku dan masukan lainnya sering menjadi kendala serius bagi pertumbuhan dan kelangsungan produksi UMKM. Industri manufaktur seperti sepatu dan tekstil misalnya, kerapkali mengalami kesulitan untuk mendapatkan bahan baku atau masukan. Hal ini tentu mempengaruhi keberlangsungan proses produksi dan operasional perusahaan secara menyeluruh.

e) Keterbatasan teknologi

Masih banyak UMKM yang menggunakan teknologi dalam bentuk mesin-mesin tua (manual). Keterbelakangan teknologi ini tidak hanya menyebabkan rendahnya produktivitas dan efisiensi, tetapi juga rendahnya mutu produk yang dihasilkan. Banyak factor yang menyebabkan keterbatasan ini, di antaranya adalah keterbatasan modal 
investasi untuk membeli mesin-mesin baru, keterbatasan informasi perkembangan teknologi (mesin-mesin dan alat-alat produksi baru), serta keterbatasan SDM yang mengoperasikan mesin-mesin baru dan melakukan inovasi-inovasi dalam produk maupun proses produksi.

f) Managerial skill

Kekurangmampuan pengusaha kecil untuk menentukan pola manajemen yang sesuai dengan kebutuhan dan tahap perkembangan usahanya berdampak pada skala usaha yang terbatas dan sulit berkembang. Dalam hal ini, manajemen merupakan seni yang dapat digunakan atau diterapkan dalam penyelenggaraan kegiatan apapun, karena dalam setiap kegiatan akan terdapat unsur perencanaan, pelaksanaan dan pengawasan.

g) Kemitraan

Kemitraan mengacu pada pengertian bekerja sama antar pengusaha dengan tingkatan yang berbeda, yaitu antara pengusaha kecil dengan pengusaha besar. Istilah kemitraan sendiri mengandung arti bahwa meskipun tingkatannya berbeda, hubungan yang terjadi merupakan hubungan yang setara (sebagai mitra), bukan bentuk hubungan yang merupakan manifestasi hubungan patron-klien.

Usaha kecil dengan karakteristik skalanya yang serba terbatas ternyata memiliki sejumlah kekuatan. Kekuatan dimaksud terletak pada kemampuan melakukan fleksibilitas dalam menghadapi berbagai tantangan lingkungan, kemampuan untuk melakukan inovasi, dan kemampuan melakukan tindakan yang tidak mungkin dilakuakn oleh pengusaha besar. Kekuatan usaha kecil di antaranya:

a) Mengembangkan kreativitas usaha baru.

b) Melakukan inovasi.

c) Kebergantungan usaha besar terhadap usaha kecil.

d) Daya tahan usaha Beberapa peneliti bidang ekonomi, bahkan menyatakan tidak lumpuhnya sama sekali perekonomian Indonesia berkat jasa pelaku usaha kecil.

\section{Daya Saing}

Daya saing merupakan faktor penting yang tidak bisa dihindarkan dalam siklus perekonomian. Khususnya dalam proses produksi barang dan jasa yang dilakukan untuk memenuhi permintaan pasar. Istilah daya saing (competitiveness), meskipun setidaknya telah "diawali" oleh konsep keunggulan komparatif (comparative advantage) oleh Ricardo sejak abad 18, kini mendapat perhatian yang semakin besar terutama tiga dekade belakangan ini. Seperti diungkapkan oleh Garelli, konsep yang multidimensi ini sangat memungkinkan beragam definisi dan pengukuran sehingga tidaklah mengejutkan jika perkembangan pandangan dan diskusi tentang daya saing tak luput dari kritik dan perdebatan (Garelli, 2003).

Patut diakui bahwa konsep daya saing yang paling diterima" adalah pada tingkat mikro. Teori ekonomi mikro secara klasik mengajarkan bahwa dalam suatu arena persaingan bisnis, perusahaan pada dasarnya mempunyai tujuan mengoptimumkan keuntungan (profit), karena keberhasilan perusahaan diindikasikan oleh keuntungan atau profitabilitasnya. Perusahaan yang tidak mampu untung (unprofitable) adalah perusahaan yang tidak berdaya saing (tidak kompetitif). Dalam model persaingan sempurna, perusahaan yang tidak berdaya saing mempunyai biaya rata-rata yang melebihi harga pasar produk yang ditawarkannya. Hal ini 
dikarenakan nilai sumber daya yang digunakan oleh perusahaan tersebut melebihi nilai produk (barang dan/atau jasa) yang diproduksi/dihasilkannya.

Beberapa bentuk persaingan yang terjadi di antaranya adalah masuknya pendatang baru, ancaman produk pengganti, kekuatan tawar menawar pembeli, kekuatan tawar-menawar pemasok (suppliers), dan persaingan di antara para pesaing yang ada. Hal ini mencerminkan bahwa ancaman persaingan tidak hanya sebatas pada sesama perusahaan dalam industri yang ada, akan tetapi juga datang dari pelanggan, pemasok, produk pengganti, serta pendatang baru potensial. Persaingan dalam artian yang lebih luas ini dapat disebut sebagai persaingan yang diperluas (extended rivalry).

Keunggulan kompetitif dapat direalisasikan dalam hal mendapatkan keunggulan strategis, taktis, maupun operasional. Pada tingkat manajerial yang tertinggi dengan tingkat perencanaan strategis, sistem informasi dapat digunakan untuk mengubah arah sebuah perusahaan dalam mendapatkan keunggulan strategisnya. Pada tingkat kendali manajemen (menengah), manajer dapat memberikan spesifikasi mengenai bagaimana rencana strategis akan diimplementasikan sehingga menciptakan suatu keunggulan taktis. Sedangkan pada tingkat kendali operasional (lebih rendah), manajer dapat menggunakan teknologi informasi dalam berbagai pengumpulan data dan penciptaan informasi yang akan memastikan efisiensi operasi, sehingga mencapai keunggulan operasional (AAker \& McLoughlin, 2010). Berikut adalah lima strategi kompetensi dasar yang dapat digunakan perusahaan dalam memenangkan persaingan, yaitu:

1) Srategi kepemimpinan biaya (cost leadership strategy)

2) Strategi diferensiasi (differentiation strategy)

3) Strategi inovasi (innovation strategy)

4) Strategi pertumbuhan (growth strategy)

5) Strategi aliansi (alliance strategy)

\section{Teknologi informasi}

Investasi pada teknologi informasi dapat mendukung perusahaan dalam bersaing. Berikut adalah gambaran peran teknologi informasi dan contoh penerapannya:

a) Penerapan teknologi informasi akan meminimalkan biaya bisnis proses, baik dalam hubungannya dengan konsumen maupun supplier.

b) Meningkatkan service/layanan yang diberikan kepada pelanggan.

c) Pemanfaatan teknologi informasi meminimalkan pesaing.

d) Inovasi produk baru yang melibatkan teknologi informasi sebagai komponennya.

e) Menciptakan pasar yang baru.

f) Meningkatkan kualitas dan efisiensi serta mempersingkat waktu layanan pelanggan.

g) Menggunakan IT untuk pengembangan bisnis (business development), mengatur bisnis secara regional dan global.

h) Membangun sistem informasi yang terhubung dengan internet dan extranet untuk support hubungan bisnis dengan costumer, supplier, subcontractor, dsb.

Pekembangan teknologi komputer dan telekomunikasi telah berhasil menciptakan infrastruktur informasi baru yang dikenal dengan istilah internet. Dalam konteks bisnis, internet membawa dampak transformasional yang menciptakan paradigma baru dalam 
berbisnis, berupa digital marketing, atau internet marketing (cyber marketing, electronic marketing, dan sejumlah istilah lainnya). Dalam konteks ini istilah internetisasi mengacu pada proses sebuah perusahaan terlibat dalam aktivitas-aktivitas bisnis secara elektronik ( $e$ commerce atau e-business), khususnya dengan memanfaatkan internet sebagai media, pasar maupun infrastruktur penunjang (Nwankwo \& Gbadamosi, 2010).

\section{E-commerce}

Pada umumnya, e-commerce berarti transaksi yang terjadi dalam internet dan web. Transaksi komersial melibatkan pertukaran nilai (misalnya uang) melintasi batas-batas organisasi atau individu sebagai imbalan atas barang dan jasa (Keneth $\mathrm{C}$. Laudon and Jane $\mathrm{P}$ . Laudon, 2007). E-commerce dimulai pada tahun 1995 ketika salah satu portal internet yang pertama, netcape.com, menerima iklan pertama dari perusahaan-perusahaan besar dan mempopulerkan ide bahwa web dapat digunakan sebagai medium baru untuk beriklan dan berjualan. Tidak ada yang pernah memimpikan bahwa penjualan eceran e-commerce ini akan mengalami kurva pertumbuhan eksponensial, yang menjadi tiga kali dan kemudian dua kali lipatnya pada tahun-tahun awalnya. Hanya pada tahun 2006 pelanggan e-commerce "melambat" dengan tingkat pertumbuhan tahunan yang mencapai 25 persen.

Revolusi e-commerce ini baru saja dimulai, akan semakin banyak orang dan perusahaan yang menggunakan internet untuk melakukan perdagangan dengan lebih banyak barang dan jasa yang dijual online dan lebih banyak rumah tangga yang mulai menggunakan telekomunikasi broadband akan lebih banyak industi yang berubah dengan adanya $e$ commerce, termasuk industri pemasaran tiket, musik dan hiburan, berita, peranti lunak, pendidikan dan keuangan.

\section{a) Kelebihan E-Commerce}

Mengapa e-commerce bertumbuh pesat? Jawabannya terdapat pada sifat unik internet internet dan teknologi e-commerce jauh lebih kaya dan canggih daripada revolusi teknologi sebelumnya. Kelebihan e-commerce:

1. Dapat dilakukan di mana saja

2. Jangkauan global

3. Standar Universal

4. Kaya Manfaat

5. Interaktif

6. Kepadatan Informasi

7. Personalisasi/Penyesuaian

\section{b) Konsep Utama dalam E-Commerce}

Model bisnis untuk menentukan lokasi, waktu, dan pendapatan didasarkan sebagian Pada biaya dan distribusi infomasi. Ketika komunikasi dibatasi pada orang-orang yang berpindah sepanjang jalur yang menghubungkan desa-desa, biaya untuk mengumpulkan informasi akan sangat tinggi, dan pasar desa menyediakan tempat bisnis dan model bisnisnya. Internet sangat mengurangi biaya untuk mendapatkan dan mendistribusikan informasi, dan menciptakan sebuah pasar digital di mana jutaan orang dapat bertukar sejumlah besar informasi secara 
langsung, cepat, dan gratis. Sebagai hasilnya, Internet telah mengubah cara perusahaan menjalankan kegiatan bisnisnya.

Internet mengurangi asimetri (ketimpangan) informasi. Ketimpangan informasi (information asymmetry) terjadi ketika salah satu pihak dalam sebuah transaksi memiliki lebih banyak informasi yang penting tentang transaksi tersebut daripada pihak lainnya.Informasi tersebut membantu menentukan daya tawar relatifnya. Di pasar digital, konsumen dan pemasok dapat melihat harga yang ditentukan untuk sebuah barang, dan dalam kondisi itu, bentuk pasar digital dikatakan lebih transparan daripada pasar tradisional.

Sebagai contoh, sampai dengan munculnya situs penjualan mobil di Web, terdapat ketimpangan informasi yang sangat terasa antara penjual dan pembeli mobil.Hanya penjual mobil yang mengetahui harga pabrik, dan sangat sulit bagi pembeli untuk membeli mobil dengan harga yang terbaik. Batas keuntungan penjual mobil bergantung pada ketimpangan informasi ini, Saat ini pembeli dapat mengakses banyak situs Web yang menyediakan informasi harga yang kompetitif, dan tiga perempat dari pembeli mobil di Amerika Serikat menggunakan Internet untuk melihat-lihat terlebih dahulu agar mendapatkan harga yang terbaik. Jadi, Web telah mengurangi ketimpangan informasi yang ada dalam pembelian mobil. Internet juga telah membantu perusahaan yang melakukan pembelian dari perusahaan lain dengan mengurangi ketimpangan informasi dan mendapatkan harga dan persyaratan yang lebih baik.

Pasar digital sangat fleksibel dan efisien karena beroperasi dengan biaya pencarian dan transaksi yang sangat kecil, biaya menu (menu cost) biaya penjual akibat perubahan harga yang lebih rendah, diskriminasi harga, dan kemampuan untuk mengubah harga dengan dinamis yang disesuaikan dengan kondisi pasar. Dalam penentuan harga dinamis (dynamic pricing), harga dari sebuah barang bergantung pada karakteristik permintaan dari konsumen atau situasi pasokan dari penjual.

Pasar digital dapat mengurangi atau menambah biaya penggantian, bergantung pada sifat produk atau layanan yang dijual, dan dapat menyebabkan penundaan kepuasan. Tidak seperti-pasar fisik, Anda tidak dapat dengan segera mengonsumsi barang, seperti membeli baju melalui Web (meskipun untuk musik digital dan produk digital lainnya, kita dapat segera mengonsumsinya).

Pasar digital memberikan banyak kesempatan untuk menjual langsung kepada pembeli, dengan melewati banyak perantara, seperti distributor atau gerai eceran. Menghilangkan perantara dalam saluran distribusi dapat sangat menurunkan biaya transaksi pembelian. Untuk membayar semua tahap dalam saluran distribusi yang tradisional, suatu barang mungkin akan dikenakan harga lebih tinggi sebesar 135 persen dari biaya produksi yang sebenarnya.

\section{c) Tipologi E-commerce}

Tiga kategori utama dari e-commerce adalah bisnis ke konsumen (B2C), bisnis ke bisnis (B2B), dan konsumen ke konsumen (C2C).

1. E-commerce bisnis ke konsumen (B2C) melibatkan penjualan produk dan layanan secara eceran kepada pembeli perorangan. 
2. E-commerce bisnis ke bisnis (B2B) melibatkan penjualan produk dan layanan antar perusahaan.

3. E-commerce konsumen ke konsumen (C2C) melibatkan konsumen yang menjual secara langsung ke konsumen.

Hampir semua transaksi e-commerce terjadi pada jaringan kabel, namun keberadaan telepon genggam dan perangkat digital nirkabel lainnya memiliki kemampuan internet yang memungkinkan kita mengirimkan pesan teks, e-mail, mengakses web, dan juga melakukan pembelian. Perusahaan-perusahaan menawarkan produk dan layanan jenis baru yang berbasis web yang dapat diakses melalui perangkat nirkabel. Penggunaan perangkat nirkabel untuk membeli produk dan layanan dari lokasi mana saja disebut perdagangan bergerak (mobile commerce atau m-commerce).

\section{METODE PENELITIAN}

Penelitian ini merupakan penelitian lapangan (field research) dengan menggunakan pendekatan kualitatif. Peneliti melakukan wawancara langsung pada beberapa pemilik UMKM yang ada di Desa Padurenan Kudus yang memanfaatkan IT dalam kegiatan pemasaran dan penjualannya. Adapun penentuan informan dalam penelitian ini menggunakan teknik purposive sampling, yaitu cara penentuan informan yang ditetapkan secara sengaja atas dasar kriteria atau pertimbangan tertentu, yaitu UMKM yang masih memanfaatkan IT dengan menggunakan e-commerce sebagai media promosi dan pemasarannya. Peneliti juga menggunakan data UMKM yang tidak menggunakan e-commerce sebagai informan pendukung dalam penelitian ini. Selanjutnya data penelitian dianalisis menggunakan model analisis data yang dirumuskan oleh Miles dan Huberman yang meliputi reduksi data, penyajian data, dan penarikan kesimpulan.

\section{Analisis Data dan Pembahasan}

Desa padurenan merupakan desa produktif yang di dalamnya banyak pengerajin bordir dan konfeksi dengan skala usaha rumah tangga. Produk yang dihasilkan dari usaha ini berupa pakaian jadi seperti kaus, kemeja, celana, jaket, dan sebagainya. Pada sekitar tahun 2000-2010 masa kejayaan usaha bordir di Kudus khususnya di Kecamatan Gebog. Namun sayangnya hal ini tidak disertai dengan peningkatan kreasi dan inovasi sehingga berdampak pada hasil produk monoton yang berdampak pada turunnya permintaan pasar. Bahkan pada beberapa tahun terakhir diperoleh data bahwa banyak produsen yang mengalami kebangkrutan dan akhirnya gulung tikar.

Kondisi ini menarik perhatian pemerintah dengan menjadikan Desa Padurenan sebagai kluster industri kerajinan border dan konveksi. Program ini akhirnya menyebabkan banyak UMKM tumbuh dan berkembang kembali di Desa Padurenan. Bahkan dalam perkembangannya produk konveksi dari Desa Padurenan sudah sampai dikirim luar kota serta luar jawa, dan bahkan ada yang sampai luar negeri. Namun demikian, masih sedikit dari UMKM yang ada memanfaatkan e-commerce sebagai media promosi dan pemasarannya.

Terdapat sekitar 160 UMKM border dan konveksi di Desa Paduranan. Dari jumlah tersebut peneliti hanya menggunakan data resmi dari Koperasi Padurenan Kudus yaitu 93 UMKM menjadi anggota koperasi dan memiliki usaha yang masih beroperasi. Pada 
kenyataanya, pengelompokkan usaha baik border maupun konveksi masih kurang jelas karena ada UMKM bordir namun juga membuat konfeksi, atau sebaliknya. Berikut adalah pembagian UMKM berdasarkan bidang konfeksi maupun bordir:

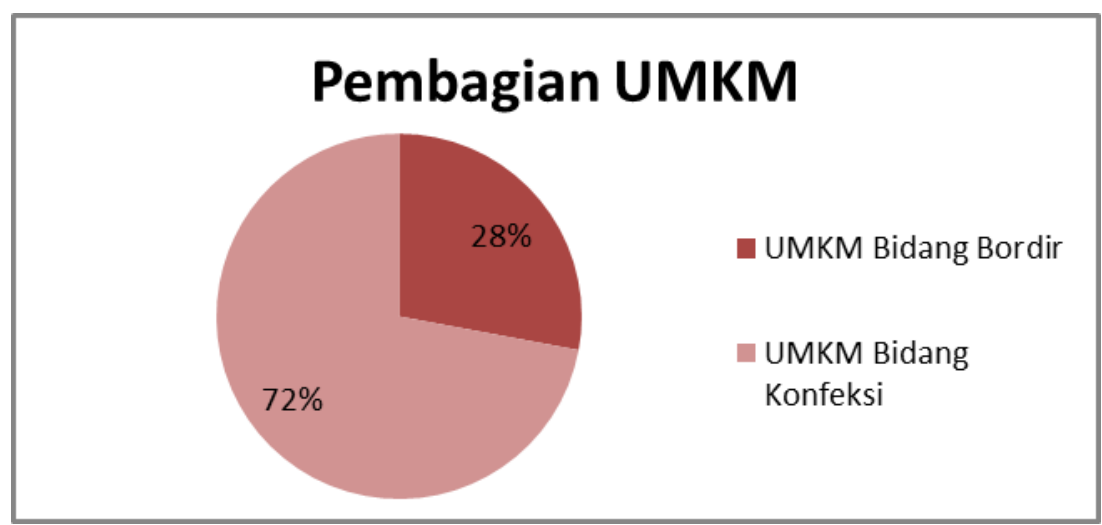

Sumber: Arsip Koperasi Padurenan Jaya Kudus, 2017

\section{Gambar 1 \\ Data Jumlah UMKM Konfeksi dan Bordir}

Keberadaan UMKM border dan konveksi terbukti berhasil mengurangi jumlah pengangguran yang ada di Desa Padurenan dan sekitarnya karena kebutuhan yang tinggi akan tenaga kerja pada bidang usaha ini.

Dalam hal pemanfaatan IT, peneliti menemukan bahwa dari 93 UMKM konfeksi dan bordir yang aktif di Desa Padurenan sebagian besar masih belum menggunakan IT dalam hal promosi dan pemasaran produknya. Hanya 25\% UMKM yang ada pernah memanfaatkan IT dalam menjual produknya. Sedangkan $75 \%$ UMKM lainnya masih menyalurkan barangnya langsung ke pasar, serta dikirim ke luar Jawa. Jenis media e-commerce media yang digunakan juga berbeda-beda, diantaranya ada yang menggunakan web, blog, media sosial, dan aplikasi toko online. Sebagaian besar UMKM menggunakan media sosial facebook. Peneliti menemukan bahwa UMKM yang sudah memiliki website dan blog masih sedikit.

Tabel 3

Data Penggunaan Media E-commerce UMKM di Desa Padurenan

\begin{tabular}{|c|c|c|c|c|}
\hline No & UMKM & Alamat web/blog & Media Sosial & Toko Online \\
\hline 1 & Bintang Mahkota & Mahkotakonveksi.com & $\begin{array}{l}\text { - Facebook : Bintang } \\
\text { Mahkota Konveksi }\end{array}$ & 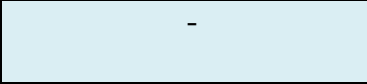 \\
\hline 2 & LEEA & $\frac{\text { https://www.semuabis.com/lee }}{12 \mathrm{~F}-0813-2564-3544}$ & $\begin{array}{l}\text { Facebook: Lapak Jual } \\
\text { beli }\end{array}$ & - \\
\hline 3 & Roberto & $\begin{array}{l}\text { https://www.semuabis.com/ro } \\
\text { berto_2K-0817-9557-576 }\end{array}$ & $\begin{array}{l}\text { Facebook : lapak jual } \\
\text { beli }\end{array}$ & \\
\hline 4 & Husna & $\begin{array}{l}\text { https://www.semuabis.com/h- } \\
\text { mulazim-0817-9542-673 }\end{array}$ & - & \\
\hline 5 & Amj Collection & & $\begin{array}{l}\text { - Facebook : Amj } \\
\text { Collection }\end{array}$ & \\
\hline 6 & Rizky Jaya & & - Facebook : Rizky Jaya & \\
\hline 7 & Melati & & $\begin{array}{l}\text { - Facebook : Melati } \\
\text { Bordir }\end{array}$ & \\
\hline 8 & Barokah Putra & Konveksikudus.com & Facebook & \\
\hline 9 & Almira & $\begin{array}{l}\text { Almirabordirkudus.blog.spot.c } \\
\text { om }\end{array}$ & $\begin{array}{l}\text { - Facebook : Almira } \\
\text { bordir kudus } \\
\text { - Instagram : }\end{array}$ & $\begin{array}{l}\text { - Shopee : Galeri_Almira } \\
\text { - Bukalapak : Varisca } \\
\text { Ardila }\end{array}$ \\
\hline
\end{tabular}




\begin{tabular}{|c|c|c|c|c|}
\hline & & & almira_bordir & \\
\hline 10 & AL- Karima & $\frac{\text { https://www.semuabis.com/al- }}{\text { karima-jp-0858-6550-1238 }}$ & - & \\
\hline 11 & HDR/ICON & Pengerajintaskudus.com & $\begin{array}{l}\text { - Facebook : Husuf } \\
\text { Efendi }\end{array}$ & \\
\hline 12 & Afif Konveksi & & $\begin{array}{l}\text { - Facebook : Afif } \\
\text { Konveksi }\end{array}$ & \\
\hline 13 & $\begin{array}{l}\text { Lida Jaya } \\
\text { Konveksi } \\
\end{array}$ & & -Facebook & \\
\hline 14 & Rumah Hafidz & $\begin{array}{l}\text { https://produsen-rumah- } \\
\text { hafidz.business.site/ }\end{array}$ & $\begin{array}{l}\text { - Facebook : Produsen } \\
\text { Rumah Hafidz } \\
\text { - Instagram : } \\
\text { Produsenrumahhafidz }\end{array}$ & $\begin{array}{l}\text { - OLX: } \\
\text { Produsenrumahhafidz } \\
\text { - Tokopedia: rumah } \\
\text { hafidz collection } \\
\text { - Shopee: koko anak } \\
\text { gamis anak supplayer } \\
\text { - Buka Lapak: Rumah } \\
\text { Hafidz }\end{array}$ \\
\hline 15 & Yazid & & $\begin{array}{l}\text {-Facebook: Yazid } \\
\text { Collection }\end{array}$ & \\
\hline 16 & Iqbal Konveksi & $\begin{array}{l}\text { https://www.semuabis.com/iqb } \\
\text { a-fashion-0812-2539-641 }\end{array}$ & $\begin{array}{l}\text { Facebook: Lapak jual } \\
\text { beli }\end{array}$ & \\
\hline 17 & As Syifa & $\begin{array}{l}\text { https://lailarossanablog.wordpr } \\
\text { ess.com/2016/07/16/as-syifa- } \\
\text { kudus-konveksi-padurenan/ }\end{array}$ & - & \\
\hline 18 & Larisma & & $\begin{array}{l}\text { - Facebook: Larisma } \\
\text { Bordir }\end{array}$ & \\
\hline 19 & Izka Bordir & $\begin{array}{l}\text { http://astrorentcarkudus.blogsp } \\
\text { ot.com/2011/05/pusat-grosir- } \\
\text { pasar-kliwon-pasar- } \\
\text { kliwon.html?m=1 }\end{array}$ & - & \\
\hline 20 & Pandawa & & $\begin{array}{l}\bullet \text { Facebook: Pandawa } \\
\text { Konveksi }\end{array}$ & \\
\hline 21 & Max Think & & $\begin{array}{l}\text { Facebook: Chalimi } \\
\text { Konveksi Maxthink } \\
\end{array}$ & \\
\hline 22 & $\begin{array}{l}\text { Sinar Jaya } \\
\text { Konveksi }\end{array}$ & $\begin{array}{l}\text { Konveksi dan Grosir Seragam } \\
\text { Kudus } \\
\text { http://sinar-jaya- } \\
\text { konveksi.business.site }\end{array}$ & $\begin{array}{l}\text { - Facebook: Sinar Jaya } \\
\text { Konveksi } \\
\text { - Instagram: Sinar Jaya } \\
\text { konveksi } \\
\end{array}$ & $\begin{array}{l}\text { - Shopee: Almahira } \\
\text { Collection } \\
\text { - Tokopedia: Sinar Jaya } \\
\text { Konveksi } \\
\end{array}$ \\
\hline 23 & Cv. Faster & & $\begin{array}{l}\text { - Facebook: Purnama } \\
\text { Faster }\end{array}$ & \\
\hline
\end{tabular}

Sumber: Data Primer diolah, 2018

Toko online juga tidak luput dari pandangan pelaku UMKM untuk mengembangkan usahanya. Pemanfaatan sistem toko online sebagai media e-commerce memberikan tantangan bagi UMKM untuk meningkatkan daya saing. Karena pada toko online seperti buka lapak, tokopedia, shopee, olx terdapat persaingan yang sangat ketat. Dengan media toko online jaringannya juga lebih luas, sehingga UMKM dapat memasarkan produknya sampai ke luar negeri. Seperti halnya rumah hafidz dan sinar jaya konveksi yang pernah menerima pesanan dari luar negeri. Sedangkan model transaksi yang digunakan dalam menjalankan e-commerce berbeda-beda, ada yang Business to Business (B2B), Business to Consumer (B2C), juga yang menerapkan keduanya. UMKM yang menerapkan B2C biasanya memasarkan produk jadi yang dijual eceran dan grosir kepada konsumen secara langsung melalui elektronik. Sedangkan untuk model transaksi B2B biasanya UMKM bekerjasama dengan lembaga atau perusahaan lain untuk memberikan jasa pembuatan seragam untuk lembaga/perusahaan 
tersebut. Selain itu, model transaksi B2B ini juga terpadi pada pembelian produk secara grosir oleh agen dan reseller.

\section{Persepsi Para Pengusaha UMKM di Desa Padurenan Kudus terhadap Peningkatan Daya Saing Melalui Pemanfaatan Teknologi Informasi dalam Bentuk E-Commerce.}

Hasil penelitian ini menunjukkan bahwa sebagian besar informan sepakat bahwa pemanfaatan e-commerce dapat memperluas jangkauan pasar. Dengan melakukan promosi dan penjualan produk dengan internet setiap orang dapat melihat produk yang dimiliki sehingga mempermudah pengenalan produk kepada calon konsumen. Tidak menutup kemungkinan jika UMKM dapat menjual produknya sampai ke pasar global. Pemesanan lewat online memudahkan konsumen untuk mencari informasi tentang produk yang dimilikinya. Pemanfaatan e-commerce juga memberikan manfaat lainnya yaitu dapat meningkatkan efisiensi bisnis karena bisnis tidak lagi terbatas oleh ruang dan waktu. Di samping itu, e-commerce menyebabkan biaya-biaya menjadi biaya terkendali dan pada akhirnya dapat meningkatkan omzet perusahaan.

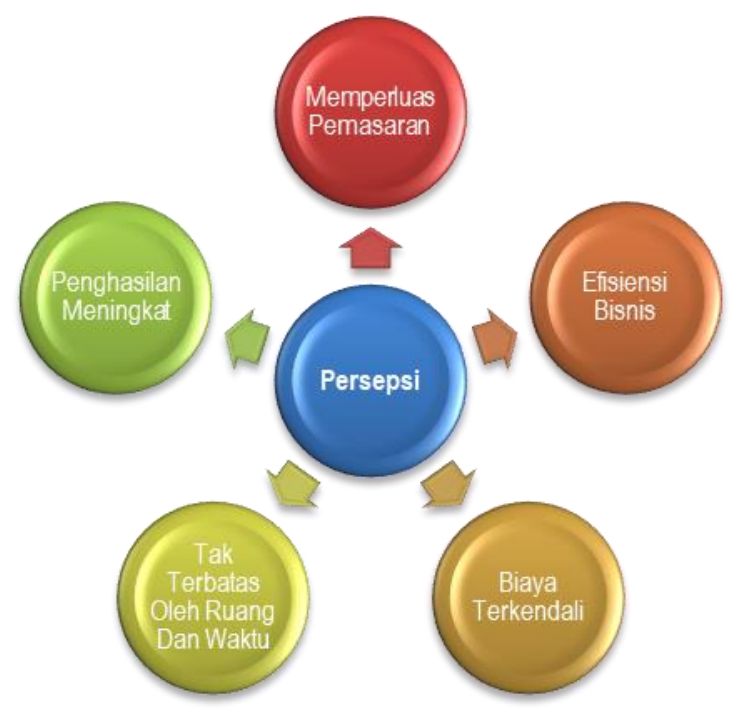

2. Deskripsi Faktor yang Mendorong dan Menghambat Pemanfaatan Teknologi Informasi dalam Bentuk E-Commerce pada UMKM di Desa Padurenan Kudus

Hasil penelitian ini menunjukkan beberapa faktor yang mendorong pemanfaatan IT dan juga pengaplikasian e-commerce bagi pelaku UMKM di Desa Padurenan yaitu yang pertama, karena mengikuti perkembangan zaman yang semakin modern dan tuntutan untuk lebih kreatif dalam menjalankan usahanya, kemudahan melakukan promosi dan pemasaran bagi UMKM, ketiadaan batas ruang dan waktu, kemudahan bertransaksi, dan keinginan untuk mengembangkan bisnis. Dari kelima faktor tersebut, kemudahan dalam promosi dan pemasaran produk serta karena ingin mengembangkan bisnis adalah factor yang paling besar mempengaruhi UMKM dalam menerapkan e-commerce.

Sedangkan faktor yang menjadi kendala dalam penerapan e-commerce yaitu kepercayaan antara penjual dan pembeli, kurangnya tenaga ahli dalam bidang IT, kekuatan di pasar offline, permintaan pasar yang overload, persaingan yang ketat, ketersediaan sarana dan prasarana IT, 
dan persepsi bahwa sistem e-commerce yang rumit. Dari faktor-faktor tersebut yang paling banyak menjadi kendala adalah persaingan yang ketat di dunia bisnis online, serta kekuatan di pasar offline (tradisional), yaitu penjualan utamanya didominasi oleh penjualan di pasar tradisional karena adanya pelanggan tetap dan nama besar yang dimilikinya.
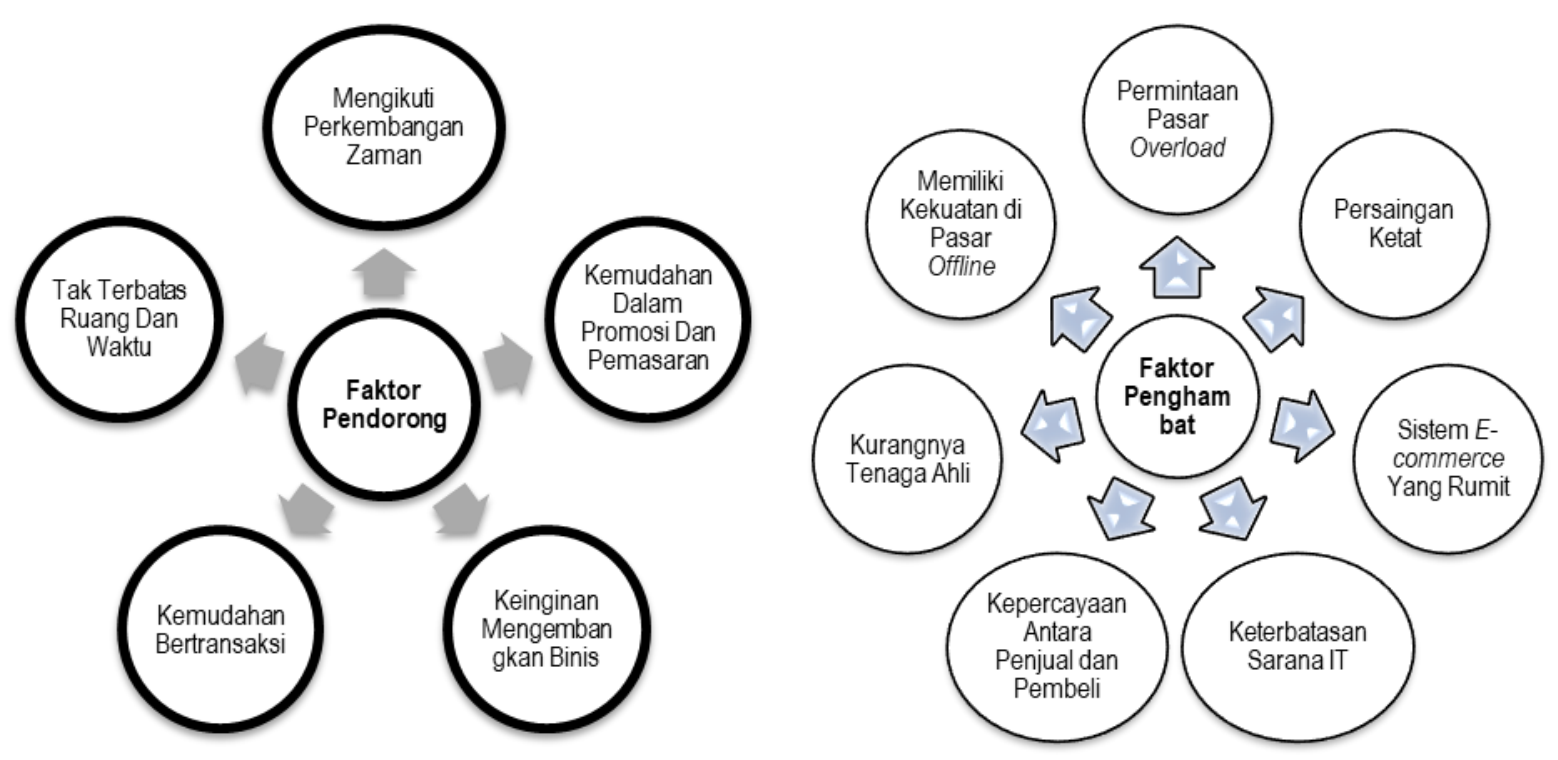

\section{Deskripsi Dampak Pemanfaatan Teknologi Informasi dalam Bentuk E-Commerce terhadap Peningkatan Daya Saing UMKM di Desa Padurenan Kudus}

Pemanfaatan IT tentu saja memiliki dampak bagi UMKM, baik dampak positif maupun negatif yang dirasakan oleh UMKM. Dampak positif yang dirasakan yaitu produk yang dipasarkan akan mudah dikenali konsumen sehingga memudahkan mendapatkan pelanggan. Dampak positif lainnya yaitu penghematan biaya promosi, meningkatkan penghasilan, dan meningkatnya kecepatan dalam bertransaksi. Pemanfaatan IT dalam bentuk e-commerce memberikan pada giliriannya akan meningkatan daya saing bagi UMKM yang ada di Desa Padurenan.

Namun, selain kelebihan yang didapatkan dalam pemanfaatan e-commerce, adapula hal negatif atau dalam dapat dikatakan sebagai konsekuensi yang didapatkan yaitu biaya investasi pengadaan IT yang dirasakan mahal, rentan terhadap tindakan penipuan dan kecurangan, serta memunculkan potensi adanya plagiator.

Tabel 8

Dampak e-commerce bagi UMKM di Desa Padurenan

\begin{tabular}{|c|c|}
\hline Dampak Positif & Dampak Negatif \\
\hline Pemasaran Meluas & Persaingan Ketat \\
\hline Menghemat Biaya & Munculnya Plagiator \\
\hline Tambah Relasi & Rawan Penipuan dan Kecurangan \\
\hline Kemudahan Bertransaksi & \\
\hline Menambah Penghasilan & \\
\hline
\end{tabular}

Pemanfaatan IT yang terjadi di UMKM Desa Padurenan merupakan strategi yang digunakan UMKM untuk meningkatkan daya saingnya. UMKM dapat menguatkan 
daya saingnya, dilihat dari sebelumnya UMKM di padurenan sudah merintis usahanya dengan penjualan secara tradisional dan sebagai strategi bersaing UMKM sekarang telah menerapkan e-commerce. Dengan menerapkan e-commerce pola bisnis UMKM juga dapat berubah, yang dahulu hanya target pada pasar tradisional dan penjualan yang masih lingkup luar kota sekarang sudah sampai seluruh Indonesia bahkan sudah sampai luar negeri.

\section{E. Kesimpulan}

Para pelaku bisnis UMKM berpandangan bahwa pemanfaatan IT dengan penerapan $e$ commerce dapat memperluas pemasaran, memberikan efisiensi bisnis, biaya operasional terkendali, tidak terbatas ruang dan waktu, dan dapat meningkatkan penghasilan. Secara garis besar pemanfaatan IT dengan menerapkan e-commerce dapat menjadi strategi bersaing yang akan meningkatkan daya saing UMKM. Hal ini ditunjukkan dengan jangkauan pemasaran UMKM bordir dan konveksi Desa Padurenan yang tidak hanya seputar Kabupaten Kudus saja, namun sudah mencapai luar Pulau Jawa bahkan sudah menjangkau luar negeri.

Seiring dengan perkembangan teknologi yang semakin pesat, pemanfaatan IT untuk keperluan bisnis menjadi sebuah keniscayaan. Dalam skala manapun keberadaan IT khususnya e-commerce dengan berbagai ragamnya menjadi sebuah kebutuhan yang harus dipenuhi. Keinginan mengikuti perkembangan zaman, adanya kemudahan dalam promosi dan pemasaran produk, keinginan dari pelaku UMKM untuk mengembangkan bisnis, kemudahan dalam bertransaksi, dan tidak adanya batasan ruang dan waktu adalah sederetan faktor yang mendukung pemanfaatan e-commerce oleh pelaku UMKM di Kabupaten Kudus. Adapun faktor yang menghambat pemanfaatan IT untuk penerapan e-commerce yaitu faktor kepercayaan antara penjual dan pembeli, kurangnya tenaga ahli, memiliki kekuatan di pasar tradisional, permintaan pasar yang overload, persaingan yang ketat, sistem e-commerce yang rumit, dan ketersediaan sarana \& prasarana yang kurang mendukung.

Dari pemanfaatan IT dalam bentuk e-commerce yang dilakukan UMKM di desa padurenan memberikan dampak pada usahanya. Dampak yang dirasakan para pelaku UMKM dengan memanfaaatkan e-commerce yaitu: 1) Pemasaran yang semakin meluas, 2) Menghemat Biaya, 3) Tambah relasi, 4) kemudahan dalam bertransaksi, 5) menambah penghasilan. Selain kelebihan-kelebihan yang didapatkan dengan menggunakan e-commerce, adapula hal negatif yang dirasakan oleh UMKM di Desa Padurenan kudus. Kalau dampak negatif yang dirasakan dengan menerapkan e-commerce yaitu: 1) Persaingan yang semakin ketat karena jangkauan pemasaran yang semakin luas dan global. 2) Munculnya plagiarisme atau penjiplakan ide dan produk 3) Rawan penipuan dan kecurangan.

\section{Referensi}

AAker, D. A., \& McLoughlin, D. (2010). Strategic Market Management: Global Perspectives (9th ed.). New Jersey.

Garelli, S. (2003). Competitiveness of Nations: The Fundamentals BT - IMD World Competitiveness Yearbook 2003. IMD World Competitiveness Yearbook 2003. Retrieved from c:\%5CUsers\%5CJuan Enrique\%5CMy Dropbox\%5CDiaspora 
Project\%5CTheoretical Framework\%5CGarelli (2003).pdf

Hafni, R., \& Rozali, A. (2017). Analisis Usaha Mikro, Kecil, dan Menengah (umkm) terhadap Penyerapan Tenaga Kerja di Indonesia. Ilmu Ekonomi Dan Studin Pembangunan, 15(2), 77-96. Retrieved from http://jurnal.umsu.ac.id/index.php/ekawan/article/view/ 1034/pdf_58

Keneth C . Laudon and Jane P . Laudon. (2007). MANAGEMENT INFORMATION SYSTEMS : Managing the Digital Firm - 9th edition, authors : Keneth C . Laudon and Jane P . Laudon ( Book Review ). International Journal, II, 103-105. https://doi.org/10.15837/ijccc.2007.1.2342

Morrison, A., Breen, J., \& Ali, S. (2003). Small Business Growth: Intention, Ability, and Opportunity. Journal of Small Business Management, 41(4), 417-425. https://doi.org/10.1111/1540-627X.00092

Niode, I. Y. (2009). Sektor UMKM Di Indonesia: Profil , Masalah, dan Strategi Pemberdayaan. Jurnal Kajian Ekonomi Dan Bisnis OIKOS-NOMOS, 2(1).

Nwankwo, S., \& Gbadamosi, A. (2010). Entrepreneurship marketing: Principles and practice of SME marketing. In Entrepreneurship Marketing: Principles and Practice of SME Marketing (pp. 1-457). https://doi.org/10.4324/9780203838648

Tan, J., Tyler, K., \& Manica, A. (2007). Business-to-business adoption of eCommerce in China. Information and Management, 44(3), 332-351. https://doi.org/10.1016/j.im.2007.04.001

Williams, M. D., Dwivedi, Y. K., Lal, B., \& Schwarz, A. (2009). Contemporary trends and issues in IT adoption and diffusion research. Journal of Information Technology, 24(1), 1-10. https://doi.org/10.1057/jit.2008.30 